\title{
The European Development Response to the Refugee and Migration Crisis ${ }^{1}$
}

\section{A. Shenfeldt}

Alina Shenfeldt - MA, Analyst, Laboratory of Anticorruption Policy, National Research University Higher School of Economics; 20 Myasnitskaya Street, 101000, Moscow, Russian Federation; E-mail: alinakashapova1993@gmail.com

\begin{abstract}
This paper is focused on the European development response to the refugee and migration crisis. European development aid was impacted by the refugee and migration crisis and appeared to be a tool to smooth the consequences of the crisis in Europe. The author conducted semi-structured interviews with scholars, policymakers and representatives of civil society and came to conclusion that the European Union (EU) and its members, instead of developing a strategic programme to resolve this structural issue, used a tactical solution to achieve the short-term goal of stopping migration. Short-term motivations prevailed over a long-term strategy and resulted in the politicization of development aid in policy papers: there was a significant change in the discourse regarding migration and development assistance. While EU members have indeed excessively used official development assistance (ODA) to host refugees in their countries, EU development programmes in African countries have been largely relabeled as "migration-related." So far there is no evidence-based research that redistribution of aid beneficiaries has taken place as a result of the policy to tackle the "root causes" of migration.

This paper first outlines the European policy framework on development assistance which is aimed at migration management. Then it identifies the EU initiatives to mainstream migration into the development agenda, and considers members' use of ODA to cover domestic expenses for refugees and asylum seekers. The paper concludes by outlining the key concerns regarding instrumentalization of aid.
\end{abstract}

Key words: ODA; migration; refugee; crisis; aid; root causes; development

For citation: Shenfeldt A. (2018) The European Development Response to the Refugee and Migration Crisis. International Organisations Research Journal, vol. 13, no 4, pp. 195-212 (in English). DOI: 10.17323/1996-7845-2018-04-09.

\section{Introduction}

Over the last three years the refugee and migration crisis has represented one of the most challenging policy issues for the European Union (EU) as thousands of people from the Middle East, Africa and Asia relocated to Europe in search of safety and dignity. This paper is focused on the response of donor countries as they tried to cope with the refugee and migration crisis. There has been a notable shift as the EU and its members' development assistance has become reoriented towards resolution of the crisis. First, the EU established the Emergency Trust Fund for Africa (largely financed by the European Development Fund) to help African countries foster stability and improve migration management.

${ }^{1}$ The editorial board received the article in August 2017. 
Second, "migration-related" projects have been advanced in the traditional development agenda of developing countries. Third, European donor countries have resorted to official development assistance (ODA) funds to tackle the domestic refugee and migration crisis.

The problem of using ODA resources to ease the migration crisis and increase the effectiveness of migration management has been widely discussed in the expert community. There are several concerns in this context, including the politicization of development assistance, the allocation of aid which is not aimed at development, and the presumably inaccurate calculation of aid in order to achieve a ratio of $0.7 \%$ between ODA and gross national income (GNI), in accordance with the United Nations' (UN) long-standing goal. This article correlates the short-term and long-term imperatives of the development assistance policy of the EU and its members with regard to the refugee and migration crisis.

Over the past decade there had been increasing interest in the migration-development nexus. It is assumed that migration can be beneficial for both receiving and home countries by promoting economic growth and reducing poverty [Nyberg-Sørensen et al., 2002; Faist, 2008]. One aspect of this agenda is the enhancement migration-related concerns in the development priorities of donor countries. The issue of "migration management" through development funds appeared prior to the current crisis. P. Weil [2002] suggested that hidden behind development intentions there is a strong interest in the forcible return of illegal immigrants.

The approach of tackling the "root causes" of migration in order to reduce migration flows has been debated among scholars. H. de Haas [2007] argued that according to empirical and theoretical evidence, with the increase of economic and human development greater capabilities and aspirations for emigration emerge, at least in the short and medium term. This argument is supported by research on the notion of the "migration hump" [Martin, Taylor, 1996], which reflects the fact that development on the horizontal axis and migration on the vertical axis will form an inverted U-shaped curve. The poorest people are too poor to migrate, whereas those who are sufficiently well-off do not feel the need to migrate in order to improve their material well-being, although migration might be an option for them for other reasons [Black, 2009].

The role of European development assistance in the current refugee and migration crisis has been analyzed by a number of researchers. J. Carling and C. Talleraas [2016] suggested that a focus on "root causes" to reduce migration flows might harm the effectiveness of development policies. L. Den Hertog [2016a] claimed that EU policymakers aspired to flexibility in "migration management" in order to respond more swiftly to humanitarian and operational needs. The author voices his concern that "funding in this area is led by emergencies rather than policy" [Den Hertog, 2016b], with a number of overlapping and competing policy papers and objectives. Another concern is the redistribution of aid among beneficiaries with the least developed countries suffering the most [Hauck et al., 2015].

A. Knoll and A. Sherriff [2017] assessed the impact of irregular migration and the refugee situation on ODA in Europe and stipulated that even despite increased costs for refugee hosting, the EU managed to make additional finances available for ODA. However, the crisis made the EU countries increase cooperation for long-term development aid with countries that are relevant from a migration perspective, therefore there is a high risk of "forgotten crises" in the short to medium term.

The Independent Commission for Aid Impact evaluated progress in the United Kingdom's aid response to irregular migration into the UK [ICAI, 2017]. According to the review, under ODA rules aid programmes may address root causes of migration as a main objective, but the goal of limiting the number of irregular migrants is only permissible as 
a secondary objective. Additionally, at the time of the review (March 2017), the UK's responsible departments had not yet elaborated a shared definition of "migration-related" aid programming, nor an agreed list of such programmes.

The hypothesis of the present paper is that in order to achieve the short-term objective of an immediate decrease of migration and refugee inflows to Europe, European donor organizations have instrumentalized development assistance.

This research draws largely on semi-structured interviews with policymakers, academics and representatives of civil society organizations (CSOs). Skype interviews were conducted with six experts while two experts completed questionnaires. There are four representatives from civil society organizations, three scholars and one policymaker. The interviewees were asked to evaluate the policies of major development agencies regarding the restructuring of development funds towards the "root causes" of migration and refugee crisis. Only one response was received out of almost 20 requests sent to national development agencies, although stating they would not be able to participate.

Representatives of civil society and human rights organizations contributed to the present study to a greater extent. Prior to the interviews, these organizations were among those which had published a number of joint open letters to European donor organizations including on the matter of reorientation of development aid to migration management and in-donor refugee costs. This research has gathered their key concerns regarding European strategy and tactics to resolve the refugee crisis.

This paper proceeds first with a discussion of the European policy framework on development assistance which is aimed at migration management. The second part proposes an outline of EU initiatives to mainstream migration into the development agenda. The third part is devoted to members' decisions to use to ODA to support the domestic costs of receiving refugees. The fourth part presents key concerns regarding the instrumentalization of aid.

Politicized aid refers to "aid policies and programmes skewed with donors' foreign policy and national security interests and formally embedded in international development strategies and humanitarian practices" [Oxfam, 2011]. Based on interviews with experts, the paper demonstrates how the crisis affected discourse about migration at the doctrinal level, and how the prevalence of short-term motivations over long-term strategy resulted in a politicization of development aid in the era of a "post-truth politics."

\section{EU Policy Framework on Migration and Development}

Increasing numbers of refugees and irregular migrants in recent years have challenged European policies. Protracted crises, terrorism, repressive regimes, inequality and poverty caused mass migration in recent years with more than 65 million forcibly displaced people worldwide [UNHCR, 2017]. In 2015, European authorities detected more than 1.8 million illegal crossings - 511,000 in 2016 [European Parliament, 2017] and 205,000 in 2017 [European Parliament, 2018].

Experts would not say that it was an unexpected outbreak - a number of protracted crises and insufficient humanitarian assistance to refugees in already overpopulated camps in Turkey, Lebanon and Ethiopia inevitably would push forcibly displaced people to look for a safer life. By May 2016, Europe had received only $6 \%$ of the world's forcibly displaced people [Edwards, 2016], whereas over half of the world's refugees were hosted in developing countries of the Middle East and Africa, with nine of the top 10 refugee-hosting countries in developing regions [UNHCR, 2017]. 
In order to propose a solid response to the challenge, European policymakers included the notion of "principled pragmatism" in their Global Strategy on Foreign and Security Policy which allowed them to combine internal and external actions for the resolution of the crisis [Mackie et al., 2017]. This comprehensive approach demands the use of development assistance to manage migration within Europe to host in-donor refugees, and also to make external contributions to cope with "root" causes that spark migration flows in developing countries.

The EU and its members collectively are the largest providers of ODA in the world with $€ 75.5$ billion in 2016 [European Commission, 2017b]. The top beneficiaries of EU aid are Turkey, India, Afghanistan, Morocco and Syria [European Commission, 2016c]. The Global Approach to Migration and Mobility (GAMM), launched in 2005 and revised in 2011, was created to serve as an overarching framework for the EU's external migration and asylum policy, complementary to its foreign policy and development cooperation [European Commission, 2011]. Maximizing the development impact of migration and mobility is presented as one of four GAMM pillars, acknowledging that good governance of migration brings vast development benefits. It is worth noting that addressing "root causes" of migration is not mentioned in the document.

With the escalation of the crisis, the GAMM was replaced by the European Agenda on Migration in 2015. In contrast with the GAMM, the discourse regarding migration has shifted such that the focus is now on providing a swift and immediate response to the crisis [European Commission, 2016b]. The pillars for EU migration policy were revised and the reduction of incentives for irregular migration by addressing its root causes came to the fore. These root causes include civil wars, persecution, poverty, unemployment and climate change, all of which should be prevented or mitigated in order to bring migration under control.

The EU delegations in key countries of origin and transit are charged with operational responsibilities to "report on migration related developments and mainstream migration issues into development cooperation" [European Commission, 2015, p. 8]. Not only should development cooperation be aimed at addressing long-term root causes of migration, but humanitarian assistance should also seek to maximize its ability also to assist refugees and serve as an instrument for addressing root causes of migration.

The European Agenda on Migration promotes the inclusion of migration issues in its foreign policy cooperation with third countries, placing the external dimension of the EU's migration policy at the core of the dialogue with key countries of origin and transit. According to the European Commission, "positive and negative incentives will be integrated into the EU's development and trade policies to reward those countries willing to cooperate effectively with the EU on migration management and ensure there are consequences for those who refuse" [European Commission, 2016b]. Though the migration-development nexus has lost much of its importance in comparison with GAMM, one of its pillars ("a new policy on legal migration") recognizes the positive effects of migration on both the EU economy and the countries of origin.

Following the European Agenda on Migration, a new Partnership Framework on Migration was forged in June 2016. This Framework is aimed at establishing a coherent, credible and effective policy to reinforce the return, readmission and reintegration of migrants, elements that are deemed essential in the fight against illegal migration. The Partnership Framework pursues the short-term objectives of increasing the rate of returns and breaking the business model of smugglers while addressing the root causes of migration in the long term.

As many as 131 non-governmental organizations (NGOs) voiced their concerns regarding the new Partnership Framework with third countries, which, according to NGOs, 
made deterrence strategies aimed at stopping migration the main objective of EU relations with developing countries [Oxfam, 2016]. NGOs claim that evidence-based approaches show the ineffectiveness of deterrence strategies which force asylum seekers to resort to more dangerous routes to seek refuge.

As a result, on the doctrinal level there appeared to be no relevant strategy that offered a long-term algorithm to guide reaction to the challenge. The GAMM appeared to be outdated, while the major focus in subsequent policy papers was on preventing illegal migration and enhancing cooperation on returns and readmission. For this reason, the longer-term objective of tackling root causes of migration seemed to become a politically correct euphemism for "curbing migration flows to Europe."

\section{Migration Management Through Development Assistance}

In order to respond more swiftly to the refugee crisis the EU created special trust funds for Africa and Turkey. The idea was to consolidate a greater amount of aid from different sources in a short period of time in order to ensure a flexible and comprehensive response to any emergency situation.

The EU Emergency Trust Fund for Africa (EUTF for Africa) was established in 2015 "for stability and addressing root causes of irregular migration and displaced persons in Africa" [European Commission, 2016a]. The fund covers 26 major countries of origin or transit for migrants with a budget of more than $\$ 2.5$ billion ( $\$ 2.4$ billion from the European Development Fund and $\$ 150$ million from the EU members).

Along with pure development objectives such as jobs creation and support for resilience in terms of food security, the focus is on migration management "in all its aspects" [European Commission, 2016a, p. 3], including the fight against illegal migration and smuggling, return and readmission, and issues related to good governance - human rights abuses, capacity building in support of security and development, and border management.

The EUTF for Africa is indeed a swift and flexible tool: according to its 2016 annual report, the process to approve an action takes only three to four months in comparison to the 12-18 months required in other development projects [European Commission, 2016d]. As a result, 106 projects had been approved by December 2016, with one-third of its funding devoted to strengthening the resilience of communities, almost a third to economic opportunities, and migration management and good governance each receiving $17 \%$ of the total budget for approved projects [p. 12]. In 2017, the allocation of funding was largely the same with community resilience projects as a priority and a slightly increased focus on migration management (23\%) [European Commission, 2017a]. However, the countries of the North of Africa received funding only for improved migration management (€285 million).

Academics tend to agree that European trust funds facilitate the use of development aid in a more coherent way in rather fragile environments, in contrast to inflexible traditional development assistance [Interviewee no 5]. However, they are mostly seen as a short-term solution that implies fast and flexible decision-making and spending; they do not have procedures to implement projects in a more forward-looking way and thus cannot be used to address long-term priorities [Interviewee no 4]. V. Hauck et al. [2015] assume that the political pressure to react swiftly and show immediate results will lead to a greater possibility that "valuable lessons of international cooperation are forgotten." In terms of the EUTF for Africa, there is a strong need for solid assessments of regional and country strategies to ensure ownership, complementarity and balance between long-term and short-term objectives. 
During an interview, a European Commission official [Interviewee no 3] admitted that the EUTFs are temporary solutions, and that there is an understanding that migration flows will increase in the future rather than diminish. Therefore, although the EUTFs have made positive contributions, long-term and structural challenges will require more solid tools to resolve.

As far as the migration-development nexus is concerned, all of the representatives of NGOs and academia approached for this research claimed that greater development leads to more migration in the short term. There is a great deal of contradiction between the insights generated from research on the migration-development nexus and the kind of policies being implemented. The apparent logic behind the EUTF for Africa is to invest in better development opportunities in Africa in order to demotivate potential migrants to leave their countries [Interviewee no 5]. However, there is not much empirical evidence to support the view that more development programmes reduce the motivations of potential migrants to migrate. As noted by an NGO representative [Interviewee no 6], "there is no matter how much research you provide, it is purely a political issue." Thus, even though policymakers are aware of what the evidence says about the correlation between development and migration, political impulses can lead them to implement an alternative policy.

However, according to an interview with a European Commission official [Interviewee no 3], what they are trying to do is not to stop migration, but rather to make it safer. The objective is to foster an environment in which migration is not the only option for people seeking to have a better life, and thus they can make a choice to stay. Therefore, instead of using the wording "root causes of migration," it might also be appropriate to say "root causes of poverty."

One of the major concerns is the reorientation of Europe's development funds toward the curbing of migration. EU policy papers put forth development aid as a leverage for migration control, which might be perceived as violation of a number of European commitments, including the Treaty of Lisbon [2007] (which stipulates that development cooperation should be used to eradicate poverty), the Busan principles on effectiveness [OECD, 2011] and the Paris principles [OECD, 2005] of ownership by and alignment to partner countries' strategies. Moreover, migration management agreements with countries in which human rights abuses take place might result in even greater inflows of migrants in the longer term. In an interview, an NGO representative [Interviewee no 6] said that donor countries resorted to development funds for short-term gains; by reducing the number of migrants coming to Europe they can show the public and the media that they are doing something about the problem.

According to an NGO representative [Interviewee no 1], most of the projects funded by the EUTF for Africa are not problematic. For example, $85 \%$ of the funding in Niger was indeed used for development programming, while the rest was dedicated to border management. This stems from the fact that many EU delegations, as well as the UN, NGOs and implementing partners, have no intention of stopping migration. But if the funding does not have the intended effect, this will give politicians the pretext to cut development funding in the future.

Some scholars interviewed for this research claim that a reorientation of development funds did not necessarily take place [Interviewee no 4, Interviewee no 5]. Instead, a great number of development projects were simply relabeled as being migration-related. This is echoed in a report by A. Knoll and A. Sheriff [2017] in which they claim that so far there have not been substantive thematic changes. However, mainstreaming migration issues 
into European development cooperation may result in programming decisions in countries that are relevant from a migration perspective.

Though there has not been a considerable shift in priorities on the ground so far, CSOs have voiced concerns that there are already discussions underway about how to introduce indicators to measure how many potential migrants were stopped from migrating, and moreover that these indicators will influence decisions about what kind of projects to implement. However, a European Commission official said that "at the political level there is a lot of pressure on a number of development actors and donors to ensure that development projects also contribute to the resolution of the perceived migration crisis," and also noted both the desire of some politicians to introduce such criteria, and the view within the development community that such demands are naïve and unrealistic to implement [Interviewee no 3].

An ICAI report [2017] points out that there are a number of problems associated with labeling traditional development projects as "migration-related." It is very hard to demonstrate the impact of a project on irregular migration, making it difficult to determine if the objectives have been achieved or to identify what works. Second, there are complex causal chains between aid and irregular migration decisions. The authors of the report claim that innovative approaches to monitoring and evaluation are needed to ensure effective new programming.

According to an interview with a policy researcher [Interviewee no 4], the re-labeling of programmes as related to "migration management" allows for more substantial funding mobilization. Though it might be criticized by NGOs and academics, tackling "root causes" of migration has become a legitimate argument in the policy arena. Therefore, though some experts and policymakers are aware of the fact that investment in development cooperation will not necessarily lead to less migration, it remains a powerful argument to mobilize funding and thus has become part of the dominant discourse.

\section{ODA for EU Members' Needs: In-donor Refugee Costs}

Apart from the joint EU response, each member of the EU has undertaken its own measures to generate funds to host refugees. One of the financial instruments to cope with the increasing number of refugees is the inclusion of costs for hosting refugees in ODA budgets. According to the reporting rules adopted in 1988 by the Development Assistance Committee (DAC) of the Organization for Economic Co-operation and Development (OECD), members are allowed to use development assistance budgets to host refugees during the first 12 months of their stay. This includes payments for transport to the host country or voluntary resettlement to a developing country and temporary sustenance such as food, shelter and training. Integration activities and forced deportation cannot be counted as ODA [OECD DAC, 2016a].

Until 2017, the DAC left the calculation of in-donor costs to the discretion of members, which hindered comparison among donors. In October 2017, the OECD DAC issued clarifications on those in-donor refugee costs that were non-eligible as ODA expenditures. It clearly stated that expenses for detention centres, border security and the costs of returning failed asylum applicants cannot be calculated as aid [2017a]. With a one-year limit being retained, the year should be calculated from the date of submission of an asylum application.

Due to the crisis, ODA funds spent on refugees more than tripled in 2016 from 2010 and accounted for $10.8 \%$ of all development aid [OECD DAC, 2017d]. As far as the EU and 
its members are concerned, this number rose to $14.2 \%$ in 2016 (from $12.9 \%$ in 2015) [European Commission, 2017b] (Fig. 1). Even though in-donor refugee costs have increased significantly, collective EU ODA has also risen, to $€ 75.5$ billion. While refugee costs increased by $€ 1.9$ billion, the overall EU ODA surged by $€ 7.6$ billion, which means that greater ODA volumes owe not only to the rise in in-donor refugee costs, but also to some additional funding [European Commission, 2016e]. However, if we take into consideration the pledge to reach the $0.7 \%$ ODA/GNI target, EU collective aid constituted $0.51 \%$ of its GNI. However, as A. Knoll and A. Sheriff [2017] have remarked, without in-donor refugee costs this number will reach a modest $0.41 \%$.

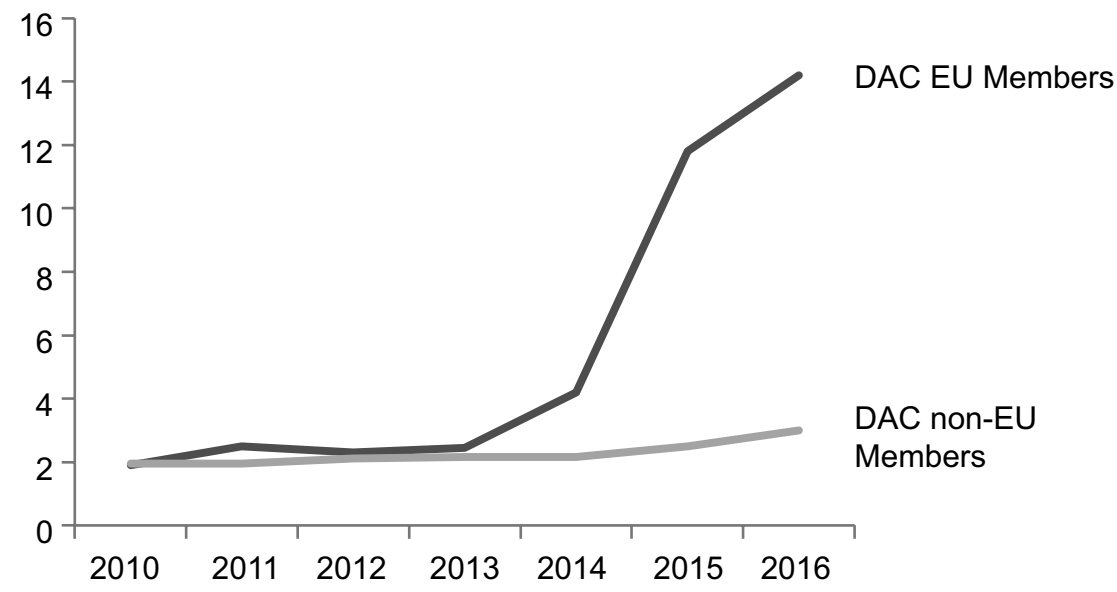

Fig. 1. Comparison of In-donor Refugee Costs as a Share of Total ODA Between DAC EU and Non-EU Members

Source: [OECD, n.d.].

Though about half of the OECD DAC members use other funds to cover hosting of refugees, some allocated more than $20 \%$ of their aid budget to refugee-related expenses in 2016: Austria allocated $37.7 \%$ of its aid as in-donor refugee costs, followed by Italy at $34.3 \%$, Germany at 25.2\%, Denmark at $17.7 \%$ and Sweden at 16.9\% [OECD DAC, 2017d] (Fig. 2). In 2015, refugees in Sweden became the main beneficiaries of Swedish aid: funding for in-donor refugee costs prevailed over bilateral support to partner countries, contributions to multilateral organizations and ODA to specific regions.

After the acute phase of the crisis had passed, allocation of ODA for in-house refugee expenses shrank in 2017 for almost all EU members of the DAC, which is indeed a good trend. However, the volume of aid that does not cross borders is still quite significant. A striking illustration of this is that EU DAC members' expenditures on in-donor refugee costs ( $\$ 9.7$ billion) were three-times more than the ODA given to the top five countries of migrants' origin - Syria, Afghanistan, Somalia, South Sudan and Sudan (\$3.2 billion) in 2016 [OECD DAC, 2017a] (Fig. 3).

CSO representatives argue that in-donor costs should not be counted as ODA since "they do not link to any development objectives of improving the welfare of poor people in developing countries" [CSO Joint Statement, 2017] They refer to the OECD DAC Secretariat's statement 15 years ago concerning the danger that including expenditures on refugees undermined the credibility of ODA. 


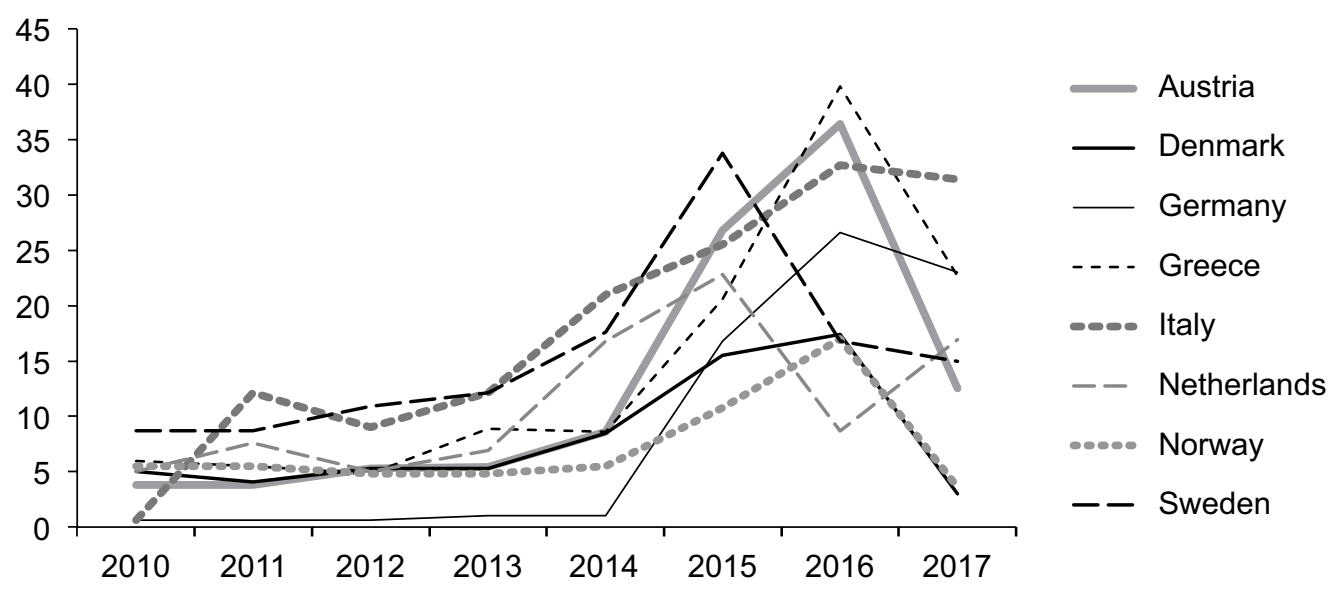

Fig. 2. In-donor Refugee Costs as a Share of Total ODA

Source: [OECD DAC, 2017d].

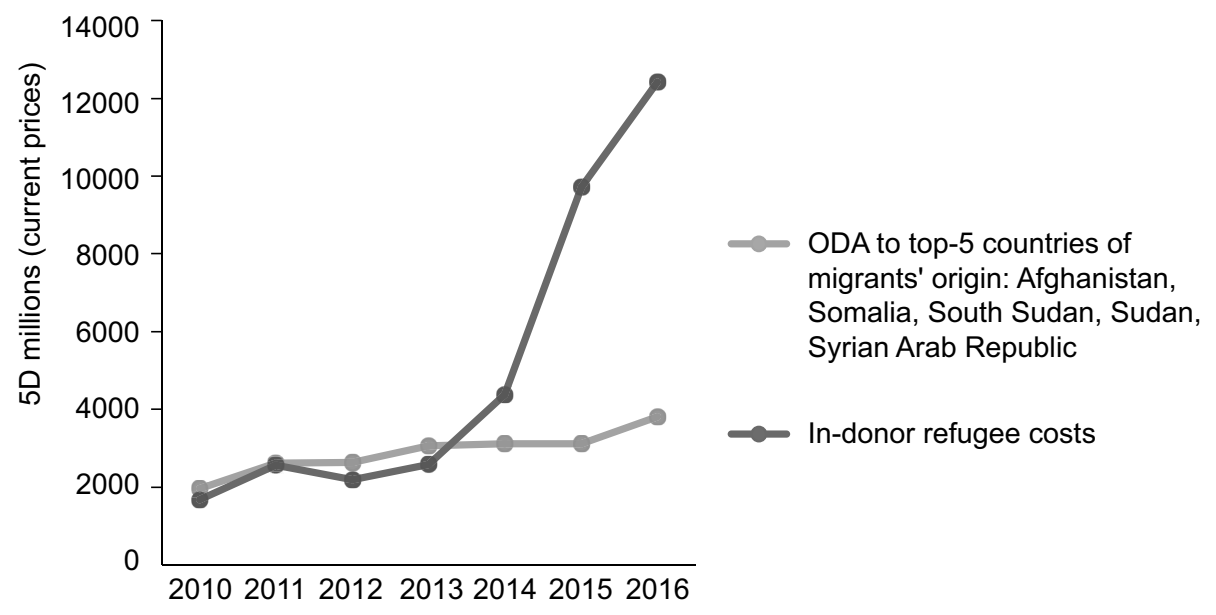

Fig. 3. Comparison of DAC EU Members' ODA Spent on In-donor Refugee Costs and Top-5 Countries of Migrants' Origin

Source: [OECD, n.d.].

There is no unanimous opinion among academics regarding ODA and in-donor refugee costs. Some claim that it is indeed not a good idea to reorient development funding to internal agencies in order to host refugees, since this is no longer development. Others tend to think that as long as a country reaches the $0.7 \%$ target for ODA/GNI, it might be acceptable to resort to this funding for the reception of refugees.

The position of the World Bank on this issue can be traced in a report where it is stated that "further increases in in-donor refugee costs could see funds diverted from development and humanitarian aid, which in turn could aggravate the forced displacement crisis" [World Bank, 2016]. Similarly, former UN Secretary-General Ban Ki Moon called this initiative "counter-productive" [Siegfried, 2015]. 


\section{Politicization of Aid and Related Concerns}

One of the main concerns among interviewees and migration and development experts is the instrumentalization of ODA. Under the Lisbon Treaty, EU development aid should be targeted toward poverty eradication. Meanwhile, trust funds allow the EU to "respond to certain emergencies and crises that are high in the political agenda at the expense of other potential crises that are less feasible, or at the expense of certain prevention measures" [Interviewee no XX]. J. Carling and C. Talleraas [2016] are also concerned with the problem, stating that "rather than targeting aid to where needs are greatest, its priorities are influenced by the EU migration agenda."

The tendency is quite disturbing since there is no attempt on the part of countries to conceal the intention to promote their own interests through development assistance. The Global Strategy for the EU's Foreign and Security Policy [European Union, 2016] is quite explicit in presenting development aid as a part of a broader foreign policy, referring to "principled pragmatism" [p. 8] as a guide to their external action, which indeed demonstrates using development aid for the broader purposes of migration management and the curbing of migration flows to Europe.

The European official [Interviewee no 3] noted that migration management should not be viewed only in negative terms. Every country has borders and a right to decide who can enter its territory, and faces the additional task of facilitating labour migration. For this reason, migration management is in the interests of developing countries, and they quite often ask the EU to foster their border management capacities. Moreover, they admit that there is pressure from some ministries to use ODA for inherent European interests, however this is not something that is taking place. In the interview, the European official was quite certain in saying that all EU development assistance fully corresponds with the ODA definition coined by the OECD DAC.

Politicization of development aid was possible also due to a significant change in the narrative about the migration crisis and development aid. Instead of talking about the opportunities that migration entails, there was a wholesale reorientation of the discourse presenting migration as a challenge, crisis and problem. The very wording used to talk about the current situation conveys certain meanings and feelings. Whereas interviewees from NGOs used the term "perceived refugee crisis," some policymakers also tend to bracket the term "refugee crisis" to express their attitude towards the perception of the situation. As one interviewee said, "the pace at which people arrive in Europe is actually perfectly manageable, it is by no means a crisis. The only reason that there was a crisis is because member states were not prepared and today they are still not, because politically they are not prepared" [Interviewee no 1].

Within the development community, there are also many concerns about the way migration has been presented in public discourse. Special Representative of the UN Secretary-General for International Migration Louise Arbour says that "the erroneous perception of an increased influx of irregular migration, combined with a lack of trust in state capacities to deal with such influxes, has led to increased intolerance and rejection of migrants" [United Nations, 2017].

Another effort to recast the refugee narrative was made by the OECD DAC which deplored the portrayal of refugees as "burdens", "dangerous infiltrators" or, at worst, as "potential terrorists." The OECD DAC claims that "narratives, whether positive or negative, can have real and meaningful policy implications" [OECD DAC, 2017c]. 
The rhetoric has also changed with regard to ODA. For European policymakers there is no longer any need to present ODA as a tool aimed exclusively at promoting economic development and the welfare of developing countries. Instead, they claim directly that positive and negative incentives will be used when allocating ODA to countries that cooperate or refuse to cooperate on the issue of return and readmission of irregular migrants. The European need to regulate domestic migration management is set at the core of its global policy, which undermines ODA credibility.

While it is quite evident that on the doctrinal level aid was instrumentalized and presented as a form of leverage, it is very important to note the risk of a potential redistribution of ODA away from recipient countries which are not "migration-related" in the short-term perspective. According to NGOs, EU desk officers are asked to redefine their objectives in relation to migration, and funds will be allocated to those countries that are relevant to migration.

However, according a European Commission official [Interviewee no 3], this criticism is unjustified. The EUTF for Africa is targeted at particular countries which indeed require additional funding to cope with the problems of border control and capacity building.

It had already been noted that experts tend to think that instead of a reorientation of funds there was considerable "relabeling" exercise to transform traditional development projects into "migration-related" projects. Furthermore, research conducted by M.A. Clemens and H.M. Postel shows that there is no clear evidence that aid disbursement follows the "root causes" rhetoric. Their assessment shows that statistics so far do not reflect a "worldwide wave of 'root causes' aid to the countries where migration is of most concerns to donors" [2018, p. 5].

In their study, M.A. Clemens and H.M. Postel referred to conceptualization of immigration policies made by H. de Haas [2013]. According to this conceptual framework, there are "policy gaps" among policy discourses, policies on paper, implementation and outcomes. In the given context we see that public discourse has indeed influenced policies on paper which put forth the identification of "root causes" as the cornerstone of ODA policy. However there is still an "implementation gap:" current research has not proved any massive reorientation of funds on the ground so far.

According to Czaika and de Haas, field studies confirm that such "implementation gaps can be sizable particularly when policies on paper are unrealistic or detached from concrete migration experiences" [2013, p. 496], which also might be the case in the current situation.

Meanwhile, instrumentalization of aid on the ground may have undesirable effects. First, implementation of migration-related projects might threaten the ownership of the third countries. The EU could spend resources on capacity building and training for border guards, but if those are not the priorities of recipient countries, such spending will neither be effective nor will it address the problem that the EU is seeking to resolve [Interviewee no 4].

From a long-term perspective, there is the possibility of exacerbating of human rights violations. According to the ICAI report [2017], migration-related programming could contribute to unintended harm to vulnerable migrants, especially in fragile environments where national law enforcement standards are poor. For example, support to coastguard or detention centers in Libya, where the right to asylum is not recognized, should be especially well-monitored.

The "principled pragmatism" of migration-related development projects and excessive use of ODA for domestic purposes can be seen partly as a response to the rising concerns of European citizens. As a result, the refugee and migration crisis has become a part of post-truth politics. "Post-truth" was chosen as the Oxford Dictionaries' word of the year 
in 2016, and it characterises the way European policymakers have approached the crisis. "Post-truth" describes circumstances when facts are less significant to the formation of public opinion than emotions and personal convictions [Oxford Dictionary, n.d.]. Indeed, the fact that Europe hosts only $6 \%$ of the world's displaced persons and due to its size and prosperity is more than capable of hosting more refugees is of "secondary" importance. According to the 2016 Humanitarian Index, many European citizens assumed that their governments had hosted significantly more refugees than they really did. For example, in the UK people tend to think that their government has taken twice as many Syrian refugees as they have done in reality. The situation is much more concerning in France and Germany, where people assume that their countries hosted five times more refugees than they actually did [Aurora Prize for Awakening Humanity, 2016].

Assessing the European response to the crisis in general, most of the interviewees think that the EU and its members proposed a short-term solution: neither the trust funds nor the domestic use of ODA can provide a long-term perspective on a protracted crisis. There has also been a shift from the focus on state capacity building to crisis management cooperation and border management ${ }^{2}$ In order to bring prosperity to the developing world, donor organizations have to operate in this post-truth environment. Development assistance did not avoid politicization, instead it was subordinated to migratory goals. With extensive use of ODA to cover in-donor refugee costs and the linkage of migration to aid, the fundamental principles of predictability of aid and aid effectiveness are undermined.

\section{Conclusions}

Having analyzed the evolution of the EU doctrinal framework on migration and development, as well as the major interventions of European development agencies, the following conclusions can be made. First, with the escalation of the crisis, on the level of policy formulation, there was no relevant strategy that could propose a long-term algorithm to guide the response to the challenge or deal with unexpectedly high flows of refugees and migrants in Europe. Moreover, no long-term strategy except for a controversial "root causes" approach has been proposed to cope with the refugee and migration crisis.

Second, in order to ease migration pressure on donor countries, donor organizations proposed a short-term solution to curb flows of migrants and refugees to Europe and cover hosting expenses for refugees in developed countries at the expense of development aid. Massive volumes of ODA were reoriented toward in-donor expenses to host refugees.

Third, the crisis affected the discourse of migration and development, with politicization of aid taking place at the doctrinal level: the "principled pragmatism" of using ODA for EU interests is formally embedded in EU policy papers. Meanwhile, due to an "implementation policy gap" there is discrepancy between the policy of addressing "root causes" of migration and its implementation on the ground. So far there has largely been only the relabeling of pure development projects into "migration-related" ones, and there is no evidence-based research that redistribution of aid beneficiaries has taken place on the ground.

Politicization of aid, even at the doctrinal level, undermines European political clout and the credibility of aid, and might have troublesome long-term consequences for the EU

${ }^{2}$ EU Common Security Defense Policy (CSDP) is implied here. CSDP is a framework for the EU to implement crisis management, crisis response operation (military or civilian) which is a very flexible and rather short-term tool. 
and its members. Further use of aid as a political tool can undermine the effectiveness of aid and may fail to ensure security both for donors and recipient communities.

The refugee and migrant crisis might provide an opportunity to reconsider development policy, since development assistance and humanitarian aid play a vital role in dealing with large-scale challenges worldwide. The crucial thing is to stick to the principles ruling the use of ODA and humanitarian aid - ownership and alignment, predictability for development aid and impartiality for humanitarian aid. Otherwise, there will be greater risks of an increase in the number of "forgotten crises" [Knoll, Sheriff, 2017], more instability in countries that are not currently countries of transit or origin of migrants, or in those countries which refuse to cooperate in the return and readmission of illegal migrants. With a high probability of future massive migration and refugee inflows, there is an urgent need for long-term vision and programming.

\section{References}

Aurora Prize for Awakening Humanity (2016) Aurora Humanitarian Index 2016. Available at: https://auroraprize.com/en/aurora/detail/9601/first-annual-humanitarian-index-released (accessed 30 August 2018).

Black R., Gent S. (2006) Sustainable Return in Post-Conflict Contexts. International Migration, vol. 44, no 3, pp. 15-38.

Carling J., Talleraas C. (2016) Root Causes and Drivers of Migration: Implications for Humanitarian Efforts and Development Cooperation. PRIO Paper, Peace Research Institute Oslo, Oslo.

Clemens M.A., Postel H.M. (2018) Deterring Emigration with Foreign Aid: An Overview of Evidence from Low-Income Countries. CGD Policy Paper 119, Center for Global Development, Washington DC. Available at: https://www.cgdev.org/sites/default/files/deterring-emigration-foreign-aid-overview-evidence-low-incomecountries.pdf (accessed 30 August 2018).

Czaika M., de Haas H. (2013) The Effectiveness of Immigration Policies. Population and Development Review, vol. 39, no 3, pp. 487-508.

De Haas H. (2007) Turning the Tide? Why Development Will Not Stop Migration. Development and Change, vol. 38, no 5, pp. 819-841.

Den Hertog L. (2016) EU Budgetary Responses to the 'Refugee Crisis:' Reconfiguring the Funding Landscape. CEPS Papers in Liberty and Security in Europe no 93, Centre for European Policy Studies, Brussels.

Edwards A. (2016) Global Forced Displacement Hits Record High. United Nations Refugee Agency (UNHCR) News. Available at: http://www.unhcr.org/afr/news/latest/2016/6/5763b65a4/global-forced-displacementhits-record-high.html (accessed 30 August 2018).

European Commission (2011) Communication on the Global Approach to Migration and Mobility.

European Commission (2015) Communication on the European Agenda on Migration.

European Commission (2016a) The EU Emergency Trust Fund For Africa: Trust Fund for Stability and Addressing Root Causes of Irregular Migration and Displaced Persons in Africa. Available at: https://eeas.europa.eu/ sites/eeas/files/factsheet_ec_format_eu_emergency_trust_fund_for_africa_2017.pdf (accessed 30 August 2018).

European Commission (2016b) Communication on Establishing a New Partnership Framework with Third Countries Under the European Agenda on Migration. Strasbourg, 7 June.

European Commission (2016c) EU Aid Explorer. Available at: https://euaidexplorer.ec.europa.eu/AidOverview.do (accessed 30 August 2018).

European Commission (2016d) EU Trust Fund for Africa: 2016 Annual Report. Available at: https://ec.europa. eu/europeaid/sites/devco/files/eutf_2016_annual_report_final_en.pdf_(accessed 30 August 2018).

European Commission (2016e) EU Official Development Assistance Reaches Highest-Ever Share of Gross National Income. Available at: http://europa.eu/rapid/press-release_IP-16-1362_en.htm (accessed 30 August 2018). 
European Commission (2017a) EU Trust Fund for Africa: 2017 Annual Report. Available at: https://ec.europa. eu/trustfundforafrica/sites/euetfa/files/2017_tffa_en_web_lowres_final05.pdf_(accessed 30 August 2018).

European Commission (2017b) EU Official Development Assistance Reaches Highest Level Ever. Available at: http://europa.eu/rapid/press-release_IP-17-916_en.htm (accessed 30 August 2018).

European Parliament (2017) Recent Migration Flows to the EU, Briefing Infographic. Available at: http:// www.europarl.europa.eu/RegData/etudes/BRIE/2017/614604/EPRS_BRI\%282017\%29614604_EN.pdf_(accessed 30 August 2018).

European Parliament (2018) Recent Migration Flows to the EU, Briefing Infographic. Available at: http:// www.europarl.europa.eu/RegData/etudes/BRIE/2018/621862/EPRS_BRI(2018)621862_EN.pdf (accessed 30 August 2018).

European Union (2016) Shared Vision, Common Action: A Stronger Europe - A Global Strategy for the European Union's Foreign and Security Policy. Available at: https://eeas.europa.eu/archives/docs/top_stories/ pdf/eugs_review_web.pdf (accessed 30 August 2018).

Faist T. (2008) Migrants as Transnational Development Agents: An Inquiry into the Newest Round of the Migration-Development Nexus. Population, Space and Place, vol. 14, no 1, pp. 21-42.

Hauck V., Knoll A., Cangas A. H. (2015) EU Trust Funds: Shaping More Comprehensive External Action? Briefing Note no 81, European Centre for Development Policy Management, Maastricht.

Independent Commission for Aid Impact (2017) The UK's Aid Response to Irregular Migration in the Central Mediterranean. Available at: https://icai.independent.gov.uk/html-report/uks-aid-response-irregular-migration-central-mediterranean/ (accessed 30 August 2018).

Joint CSO Statement to the OECD DAC members (2017) https://www.oecd.org/dac/CSO\%20inputs\%20 on $\% 20$ clarification $\% 20 \mathrm{of} \% 20$ rules $\% 20 \mathrm{on} \% 20 \mathrm{ODA} \% 20$ to $\% 20 \mathrm{in}$-donor\%20refugee $\% 20$ costs.pdf (accessed 30.08.2018)

Knoll A., Sheriff A. (2017) Making Waves: Implications of the Irregular Migration and Refugee Situation on Official Development Assistance Spending and Practices in Europe. ECDPM Contributing Document, European Centre for Development Policy Management, Maastricht.

Mackie J., Deneckere M., Galeazzi G. (2017) Matching Means to Priorities: Challenges for EU-Africa Relations in 2017. ECDPM Challenges Paper Issue no 8, European Centre for Development Policy Management, Maastricht.

Martin P.L., Taylor J.E. (1996) The Anatomy of a Migration Hump. Development Strategy, Employment, and Migration: Insights from Models (J.E. Taylor (ed)). Paris: OECD, pp. 43-62.

Nyberg-Sørensen N., Van Hear N., Engberg-Pedersen P. (2002) The Migration - Development Nexus: Evidence and Policy Options State-of-the-Art Overview. International Migration, vol. 40, no 5, pp. 3-47.

Organisation for Economic Co-operation and Development (OECD) (n.d.) Statistics on Development. Available at: https://data.oecd.org/development.htm (accessed 30 August 2018).

Organisation for Economic Co-operation and Development (OECD) (2005) The Paris Declaration on Aid Effectiveness and the Accra Agenda for Action. Available at: http://www.oecd.org/dac/effectiveness/34428351. pdf (accessed 30 August 2018).

Organisation for Economic Co-operation and Development (OECD) (2011) Busan Partnership for Effective Development Co-operation. Available at: http://www.oecd.org/dac/effectiveness/49650173.pdf_(accessed 30 August 2018).

Organisation for Economic Co-operation and Development - Development Assistance Committee (OECD DAC) (2016a) Methodologies for Reporting In-donor Refugee Costs. Paris. Available at: https://www.oecd. org/dac/stats/RefugeeCostsMethodologicalNote.pdf ( (accessed 30 August 2018).

Organisation for Economic Co-operation and Development - Development Assistance Committee (OECD DAC) (2016b) Development Aid Rises Again in 2015, Spending on Refugees Doubles. Available at: http:// www.oecd.org/dac/development-aid-rises-again-in-2015-spending-on-refugees-doubles.htm (accessed 30 August 2018). 
Organisation for Economic Co-operation and Development - Development Assistance Committee (OECD DAC) (2017a) Clarifications to the Statistical Reporting Directives on In-Donor Refugee Costs. Available at: http://www.oecd.org/officialdocuments/publicdisplaydocumentpdf/?cote=DCD/DAC(2017)35/ FINAL\&docLanguage $=$ En (accessed 30 August 2018).

Organisation for Economic Co-operation and Development - Development Assistance Committee (OECD DAC) (2017b) Table 1: Net Official Development Assistance from DAC and Other Donors in 2016.

Organisation for Economic Co-operation and Development - Development Assistance Committee (OECD DAC) (2017c) Refugee Realities: Policy-Making and Recreating the Refugee Narrative. Available at: https:// www.oecd.org/dac/Refugee_Realities_Concept_Note_May\%2019.pdf (accessed 30 August 2018).

Organisation for Economic Co-operation and Development - Development Assistance Committee (OECD DAC) (2017d) Development aid rises again in 2016. Available at: http://www.oecd.org/dac/financing-sustainable-development/development-finance-data/ODA-2016-detailed-summary.pdf (accessed 30 August 2018).

Oxfam (2011) Whose Aid is it Anyway? Politicizing Aid in Conflicts and Crises. Briefing Paper no 145. Available at: https://www.oxfam.org/sites/www.oxfam.org/files/bp145-whose-aid-anyway-100211-en_0.pdf_(accessed 30 August 2018).

Oxfam (2016) Joint NGO Statement Ahead of the European Council of 28-29 June 2016. Available at: https:// www.oxfam.org/sites/www.oxfam.org/files/file_attachments/jointstatementeumigrationresponse.pdf (accessed 30 August 2018).

Oxford Dictionaries (n.d.) Word of the Year 2016. Available at https://en.oxforddictionaries.com/word-of-theyear/word-of-the-year-2016 (accessed 30 August 2018).

Siegfried K. (2015) How the Refugee Crisis is Hurting Foreign Aid. IRIN, 18 November. Available at: http:// www.irinnews.org/report/102225/how-refugee-crisis-hurting-foreign-aid (accessed 30 August 2018).

World Bank (2016) Conference: Forcibly Displaced: Toward A Development Approach Supporting Refugees, the Internally Displaced, and Their Hosts, Washington DC, 15 September.

Treaty of Lisbon (2007) Available at: http://publications.europa.eu/resource/cellar/688a7a98-3110-4ffe-a6b38972d8445325.0007.01/DOC_19 (accessed 30 August 2018).

United Nations Refugee Agency (UNHCR) (2017) Global Trends - Forced Displacement in 2016. UNHCR Report. Available at: http://www.unhcr.org/globaltrends2016/ (accessed 30 August 2018).

United Nations (UN) (2017) Consultations on Migration Compact Begin; UN Envoy Urges Policies that Reject 'Us vs. Them' Tactics. UN News Centre, 8 May. Available at: https://refugeesmigrants.un.org/consultationsmigration-compact-begin-un-envoy-urges-policies-reject-'us-vs-them'-tactics (accessed 30 August 2018).

Weil P. (2002) Towards a Coherent Policy of Co-Development. International Migration, vol. 40, no 3, pp. $41-56$.

\section{Annex A: List of interviewees}

1. Anonymous, NGO (Questionnaire in March 2017);

2. Anonymous, think-tank (Interview in April 2017);

3. European Commission Official (Interview in March 2017).

4. Den Hertog, Leonhard. Centre for European Policy Studies (Interview in March 2017);

5. Deneckere, Matthias. European Centre for Development Policy Management (Interview in March 2017);

6. Jeune, Hilary. Oxfam International (Interview in March 2017);

7. Simons, Rupert. Publish What You Fund (Interview in March 2017);

8. Vanderstappen, Cecile. CNCD-11.11.11 (Questionnaire in April 2017). 


\title{
Использование политики в целях развития для разрешения миграционного кризиса в Европе ${ }^{1}$
}

\author{
А.А. Шенфельдт
}

Шенфельдт Алина Азатовна - магистр политических наук, аналитик Лаборатории антикоррупционной политики Национального исследовательского университета «Высшая школа экономики»; Российская Федерация, 103070, Москва, Кривоколенный пер., д. 3; E-mail: alinakashapova1993@gmail.com

В фокусе статьи - использование европейскими странами политики по содействию развитию для разрешения миграционного кризиса. Европейская помощь в целях развития (ОПР) не избежсала воздействия со стороны миграционного кризиса и стала инструментом для сглаживания его последствий в странах ЕС. Проведя полустандартизированные интервью с исследователями, должностными лицами и представителями гражданского общества, автор статьи делает вывод, что вместо стратегического планирования по разрешению проблемы, носящей структурный характер, ЕС и страны-члены приняли тактическое решение для достижения краткосрочной цели сдерживания миграции. В результате произошла политизация помощи в целях развития на доктринальном уровне и существенно изменился политический дискурс по вопросам миграции и ОПР. При этом, в то время как страны - члены ЕС действительно прибегли к чрезмерному использованию ОПР для приема беженцев в своих странах, многие программы развития ЕС в африканских странах были переименованы в программы, важные с миграционной точки зрения. В настоящий момент нет исследований, демонстрирующих, что произошло перераспределение помощи между странами-бенефициарами в результате политики борьбы с «коренными причинами» миграции.

Статья начинается с описания европейских политических рамок по использованию политики содействия развитию для управления миграцией. Далее описываются инициативы ЕС, направленные на продвижение вопросов миграции в повестку содействия развитию, и анализируется подход стран - членов ЕС к использованию ОПР для приема беженцев. В заключительном разделе перечисляются основные проблемы, связанные с инструментализацией ОПР.

Ключевые слова: ОПР; миграция; кризис беженцев; миграционный кризис; помощь; коренные причины; развитие

Для цитирования: Шенфельдт А.А. (2018) Использование политики в целях развития для разрешения миграционного кризиса в Европе // Вестник международных организаций. Т. 13. № 4. С. 195-212 (на русском и английском языках). DOI: 10.17323/1996-7845-2018-04-09.

\section{Источники}

Aurora Prize for Awakening Humanity (2016) Aurora Humanitarian Index 2016. Режим доступа: https://auroraprize.com/en/aurora/detail/9601/first-annual-humanitarian-index-released (дата обращения: 30.08.2018).

Black R., Gent S. (2006) Sustainable Return in Post-Conflict Contexts // International Migration. Vol. 44. No. 3. P. $15-38$.

Carling J., Talleraas C. (2016) Root Causes and Drivers of Migration: Implications for Humanitarian Efforts and Development Cooperation. Oslo: PRIO Paper.

Clemens M.A., Postel H.M. (2018) Deterring Emigration with Foreign Aid: An Overview of Evidence from LowIncome Countries. CGD Policy Paper 119, Center for Global Development, Washington DC. Режим доступа: https://www.cgdev.org/sites/default/files/deterring-emigration-foreign-aid-overview-evidence-low-incomecountries.pdf (дата обращения: 30.08.2018).

Czaika M., de Haas H. (2013) The Effectiveness of Immigration Policies // Population and Development Review. Vol. 39. No. 3. P. 487-508.

\footnotetext{
${ }^{1}$ Статья поступила в редакцию в августе 2017 г.
} 
De Haas H. (2007) Turning the Tide? Why Development Will Not Stop Migration // Development and Change. Vol. 38. No. 5. P. 819-41.

Den Hertog L. (2016) EU Budgetary Responses to the 'Refugee Crisis:' Reconfiguring the Funding Landscape. CEPS Papers in Liberty and Security in Europe no 93, Centre for European Policy Studies, Brussels.

Edwards A. (2016) Global Forced Displacement Hits Record High. United Nations Refugee Agency (UNHCR) News. Режим доступа: http://www.unhcr.org/afr/news/latest/2016/6/5763b65a4/global-forced-displacement-hits-record-high.html (дата обращения: 30.08.2018).

European Commission (2011) Communication on the Global Approach to Migration and Mobility.

European Commission (2015) Communication on the European Agenda on Migration.

European Commission (2016a) The EU Emergency Trust Fund for Africa: Trust Fund for Stability and Addressing Root Causes of Irregular Migration and Displaced Persons in Africa. Режим доступа: https://eeas. europa.eu/sites/eeas/files/factsheet_ec_format_eu_emergency_trust_fund_for_africa_2017.pdf (дата обращения: 30.08.2018).

European Commission (2016b) Communication on Establishing a New Partnership Framework with Third Countries Under the European Agenda on Migration. Strasbourg, 7 June.

European Commission (2016c) EU Aid Explorer. Режим доступа: https://euaidexplorer.ec.europa.eu/AidOverview.do (дата обращения: 30.08 .2018 ).

European Commission (2016d) EU Trust Fund for Africa: 2016 Annual Report. Режим доступа: https:// ec.europa.eu/europeaid/sites/devco/files/eutf_2016 annual_report final_en.pdf (дата обращения: 30.08.2018).

European Commission (2016e) EU Official Development Assistance Reaches Highest-Ever Share of Gross National Income. Режим доступа: http://europa.eu/rapid/press-release_IP-16-1362_en.htm (дата обращения: 30.08.2018).

European Commission (2017a) EU Trust Fund for Africa: 2017 Annual Report. Режим доступа: https:// ec.europa.eu/trustfundforafrica/sites/euetfa/files/2017_tffa_en_web_lowres_final05.pdf_(дата обращения: 30.08.2018).

European Commission (2017b) EU Official Development Assistance Reaches Highest Level Ever. Режим доступа: http://europa.eu/rapid/press-release_IP-17-916_en.htm_(дата обращения: 30.08.2018).

European Parliament (2017) Recent Migration Flows to the EU, Briefing Infographic. Режим доступа: http:// www.europarl.europa.eu/RegData/etudes/BRIE/2017/614604/EPRS_BRI\%282017\%29614604_EN.pdf (дата обращения: 30.08.2018).

European Parliament (2018) Recent Migration Flows to the EU, Briefing Infographic. Режим доступа: http:// www.europarl.europa.eu/RegData/etudes/BRIE/2018/621862/EPRS_BRI(2018)621862_EN.pdf_(дата обращения: 30.08.2018).

European Union (2016) Shared Vision, Common Action: A Stronger Europe - A Global Strategy for the European Union's Foreign and Security Policy. Режим доступа: https://eeas.europa.eu/archives/docs/top_stories/pdf/eugs_review_web.pdf (дата обращения: 30.08.2018).

Faist T. (2008) Migrants as Transnational Development Agents: An Inquiry into the Newest Round of the Migration-Development Nexus // Population, Space and Place. Vol. 14. No. 1. P. 21-42.

Hauck V., Knoll A., Cangas A.H. (2015) EU Trust Funds: Shaping More Comprehensive External Action? Briefing Note no 81, European Centre for Development Policy Management, Maastricht.

Independent Commission for Aid Impact (2017) The UK's Aid Response to Irregular Migration in the Central Mediterranean. Режим доступа: https://icai.independent.gov.uk/html-report/uks-aid-response-irregularmigration-central-mediterranean/ (дата обращения: 30.08.2018).

Joint CSO Statement to the OECD DAC members (2017) Режим доступа: https://www.oecd.org/dac/ CSO $\% 20$ inputs $\% 20$ on $\% 20$ clarification $\% 20$ of $\% 20$ rules $\% 20$ on $\% 20$ ODA $\% 20$ to $\% 20$ in-donor $\% 20$ refugee $\% 20$ costs.pdf (дата обращения: 30.08.2018).

Knoll A., Sheriff A. (2017) Making Waves: Implications of the Irregular Migration and Refugee Situation on Official Development Assistance Spending and Practices in Europe. ECDPM Contributing Document, European Centre for Development Policy Management, Maastricht.

Mackie J., Deneckere M., Galeazzi G. (2017) Matching Means to Priorities: Challenges for EU-Africa Relations in 2017. ECDPM Challenges Paper Issue no 8, European Centre for Development Policy Management, Maastricht. 
Martin P.L., Taylor J.E. (1996) The Anatomy of a Migration Hump. Development Strategy, Employment, and Migration: Insights from Models (J.E. Taylor (ред.)). Paris: OECD. P. 43-62.

Nyberg-Sørensen N., Van Hear N., Engberg-Pedersen P. (2002) The Migration-Development Nexus: Evidence and Policy Options State-of-the-Art Overview // International Migration. Vol. 40. No 5. P. 3-47.

Organisation for Economic Co-operation and Development (OECD) (n.d.) Statistics on Development. Peжим доступа: https://data.oecd.org/development.htm (дата обращения: 30.08.2018).

Organisation for Economic Co-operation and Development (OECD) (2005) The Paris Declaration on Aid Effectiveness and the Accra Agenda for Action. Режим доступа: http://www.oecd.org/dac/effectiveness/34428351.pdf_(дата обращения: 30.08.2018).

Organisation for Economic Co-operation and Development (OECD) (2011) Busan Partnership for Effective Development Co-operation. Режим доступа: http://www.oecd.org/dac/effectiveness/49650173.pdf (дата обращения: 30.08.2018).

Organisation for Economic Co-operation and Development - Development Assistance Committee (OECD DAC) (2016a) Methodologies for Reporting In-donor Refugee Costs. Paris. Режим доступа: https://www. oecd.org/dac/stats/RefugeeCostsMethodologicalNote.pdf (дата обращения: 30.08.2018).

Organisation for Economic Co-operation and Development - Development Assistance Committee (OECD DAC) (2016b) Development Aid Rises Again in 2015, Spending on Refugees Doubles. Режим доступа: http:// www.oecd.org/dac/development-aid-rises-again-in-2015-spending-on-refugees-doubles.htm (дата обращения: 30.08.2018).

Organisation for Economic Co-operation and Development - Development Assistance Committee (OECD DAC) (2017a) Clarifications to the Statistical Reporting Directives on In-Donor Refugee Costs. Режим доступа: http://www.oecd.org/officialdocuments/publicdisplaydocumentpdf/?cote=DCD/DAC(2017)35/ FINAL\&docLanguage=En (дата обращения: 30.08.2018).

Organisation for Economic Co-operation and Development - Development Assistance Committee (OECD DAC) (2017b) Table 1: Net Official Development Assistance from DAC and Other Donors in 2016.

Organisation for Economic Co-operation and Development - Development Assistance Committee (OECD DAC) (2017c) Refugee Realities: Policy-Making and Recreating the Refugee Narrative. Режим доступа: https://www.oecd.org/dac/Refugee_Realities_Concept_Note_May\%2019.pdf (дата обращения: 30.08.2018).

Organisation for Economic Co-operation and Development - Development Assistance Committee (OECD DAC) (2017d) Development aid rises again in 2016. Режим доступа: http://www.oecd.org/dac/financingsustainable-development/development-finance-data/ODA-2016-detailed-summary.pdf (дата обращения: 30.08.2018).

Oxfam (2011) Whose Aid is it Anyway? Politicizing Aid in Conflicts and Crises. Briefing Paper no 145. Peжим доступа: https://www.oxfam.org/sites/www.oxfam.org/files/bp145-whose-aid-anyway-100211-en_0. pdf_(дата обращения: 30.08.2018).

Oxfam (2016) Joint NGO Statement Ahead of the European Council of 28-29 June 2016. Режим доступа: https://www.oxfam.org/sites/www.oxfam.org/files/file_attachments/jointstatementeumigrationresponse.pdf (дата обращения: 30.08.2018).

Oxford Dictionaries (n.d.) Word of the Year 2016. Режим доступа: https://en.oxforddictionaries.com/wordof-the-year/word-of-the-year-2016 (дата обращения: 30.08.2018).

Siegfried K. (2015) How the Refugee Crisis is Hurting Foreign Aid. IRIN, 18 November. Режим доступа: http://www.irinnews.org/report/102225/how-refugee-crisis-hurting-foreign-aid (дата обращения: 30.08.2018).

World Bank (2016) Conference: Forcibly Displaced: Toward A Development Approach Supporting Refugees, the Internally Displaced, and Their Hosts, Washington DC, 15 September.

Treaty of Lisbon (2007) Режим доступа: http://publications.europa.eu/resource/cellar/688a7a98-3110-4ffea6b3-8972d8445325.0007.01/DOC_19 (дата обращения: 30.08.2018).

United Nations Refugee Agency (UNHCR) (2017) Global Trends - Forced Displacement in 2016. UNHCR Report. Режим доступа: http://www.unhcr.org/globaltrends2016/ (дата обращения: 30.08.2018).

United Nations (UN) (2017) Consultations on Migration Compact Begin; UN Envoy Urges Policies that Reject 'Us vs. Them' Tactics. UN News Centre, 8 Мау. Режим доступа: https://refugeesmigrants.un.org/consultations-migration-compact-begin-un-envoy-urges-policies-reject-'us-vs-them'-tactics (дата обращения: 30.08.2018).

Weil P. (2002) Towards a Coherent Policy of Co-Development // International Migration. Vol. 40. No. 3. P. 41-56. 